\title{
Muscle and bone plasticity after spinal cord injury: Review of adaptations to disuse and to electrical muscle stimulation
}

\author{
Shauna Dudley-Javoroski, PT; Richard K. Shields, PhD, PT* \\ Graduate Program in Physical Therapy and Rehabilitation Science, The University of Iowa, Iowa City, IA
}

\begin{abstract}
The paralyzed musculoskeletal system retains a remarkable degree of plasticity after spinal cord injury (SCI). In response to reduced activity, muscle atrophies and shifts toward a fast-fatigable phenotype arising from numerous changes in histochemistry and metabolic enzymes. The loss of routine gravitational and muscular loads removes a critical stimulus for maintenance of bone mineral density (BMD), precipitating neurogenic osteoporosis in paralyzed limbs. The primary adaptations of bone to reduced use are demineralization of epiphyses and thinning of the diaphyseal cortical wall. Electrical stimulation of paralyzed muscle markedly reduces deleterious post-SCI adaptations. Recent studies demonstrate that physiological levels of electrically induced muscular loading hold promise for preventing post-SCI BMD decline. Rehabilitation specialists will be challenged to develop strategies to prevent or reverse musculoskeletal deterioration in anticipation of a future cure for SCI. Quantifying the precise dose of stress needed to efficiently induce a therapeutic effect on bone will be paramount to the advancement of rehabilitation strategies.
\end{abstract}

Key words: adaptation, bone, electrical stimulation, muscle, musculoskeletal deterioration, osteoporosis, plasticity, pQCT, rehabilitation, soleus, spinal cord injury.

\section{INTRODUCTION}

Annually, spinal cord injury (SCI) occurs in 10,000 to 20,000 individuals and costs society between $\$ 4$ billion and $\$ 7$ billion [1]. Secondary complications of SCI, including degradation of the musculoskeletal system of the paralyzed limbs, contribute to these costs. Paralyzed tissue below the level of a clinically "complete" SCI has enormous capacity to adapt. Rehabilitation specialists must find innovative strategies to improve the health quality of people with SCI and preserve the integrity of the musculoskeletal system in anticipation of a future cure. This review describes (1) the adaptations that muscle and bone undergo after paralysis from SCI and (2) recent findings suggesting that timely introduction of physiological stress will prevent significant musculoskeletal deterioration. We highlight issues such as potential neural contributions to bone and muscle remodeling and the need for dose-response relationships.

\footnotetext{
Abbreviations: ATPase $=$ adenosine triphosphatase, $\mathrm{BDNF}=$ brain-derived neurotrophic factor, BMD = bone mineral density, DEXA = dual-energy X-ray absorptiometry, GDNF = glial cell line-derived neurotrophic factor, $\mathrm{MHC}=$ myosin heavy chain, NT-3 = neurotrophin 3, pQCT = peripheral quantitative computed tomography, SCI = spinal cord injury, SDH = succinate dehydrogenase, SERCA $=$ sarcoplasmic reticulum $\mathrm{Ca}^{2+}$ ATPase.

*Address all correspondence to Richard K. Shields, PhD, PT; Graduate Program in Physical Therapy and Rehabilitation Science, 1-248 Medical Education Building, The University of Iowa, 248 Newton Road, Iowa City, IA 522421190; 319-335-9803. Email: Richard-shields@uiowa.edu DOI: 10.1682/JRRD.2007.02.0031
} 


\section{GENERAL OVERVIEW: MUSCULOSKELETAL DETERIORATION AFTER SCI}

All individuals with clinically complete SCI have some degree of musculoskeletal deterioration [2]. One only needs to look closely enough to find various levels of muscle, bone, and integument changes resulting from paralysis. For this review, we will focus on individuals with complete SCI without lower motor neuron lesions.

As a result of paralysis, individuals with SCI enter a period of "metabolic chaos," defined as an extreme catabolic state triggered by the loss of physiological stress to tissue. Rapid atrophy of paralyzed muscle floods the circulatory system with protein degradation by-products, increasing the demands on the kidneys. The loss of muscle force contributes to bone demineralization (as much as $2 \%-4 \%$ a month) [3]. The kidneys resorb and excrete large quantities of calcium and other minerals from the blood. Not surprisingly, bone demineralization after paralysis is associated with hypercalciuria [4-7], renal uretolithiasis [4], and bladder stones [8]. A primary comorbidity in individuals with SCI is renal failure [1], which may be related to high blood calcium levels and the incidence of ureter calculi [9].

As much as 50 percent of the mineral content of bones in paralyzed limbs may be lost within the first 3 years after SCI [10-12]. Fractures may occur with minimal inciting trauma [13], often during routine activities of daily living such as dressing, bathing, and transferring to and from a wheelchair. Hence, the complications associated with a degenerating musculoskeletal system are serious and widespread.

\section{MUSCLE ADAPTATIONS TO SCI}

Under normal conditions, the majority of whole human muscles are composed of a mixture of fast and slow muscle fibers. Chronic SCI triggers a transformation from slow, fatigue-resistant muscle to fast, fatigable muscle in humans [14-17] and rats [18]. These changes in contractile properties covary with histochemical changes in myosin adenosine triphosphatase (ATPase) [14] myosin light chains and/ or myosin heavy chains (MHCs) [16,19-22], sarcoplasmic reticulum $\mathrm{Ca}^{2+}$ ATPase (SERCA) isoforms [19], oxidative capacity via nicotinamide adenine dinucleotide [14] or succinate dehydrogenase (SDH) [21], and glucose transport proteins GLUT1 and GLUT4 [23]. All these adaptations are consistent with faster fatigable muscle fiber types. Conversely, no decrease [24], or even an increase [25], in oxidative enzyme capacity (SDH) has occasionally been observed with MHC shifts to faster phenotypes after SCI. This finding suggests a possible dissociation between oxidative capacity and other muscle fiber type-specific factors. Further, the consistently observed MHC transition after SCI in multiple species includes hybrid expression of MHC isoforms [19,26-28], presumably because of changes in MHC protein expression at the fiber level. Hybrid MHC expression is not typically observed in muscle under normal neuromuscular conditions. However, whether fiber hybridization is a transient phenomenon [16] or a steady state condition [26] after SCI is unclear.

Muscle atrophy has long been recognized as a cardinal sequela of complete SCI [21]. Although atrophy may preferentially occur in slow muscle fibers [29], others would conclude that muscle atrophy is independent of fiber type $[25,30]$. Muscle protein transformations and fiber atrophy after SCI may be dissociated from one another. Atrophy may occur more rapidly after SCI than MHC isoform transformations [20]. Six weeks after SCI, human lower-limb muscles were 45 percent smaller than controls [31]. The timeline for MHC transition in humans is controversial. At 4 weeks, minimal MHC transformation was observed [16]; an MHC hybrid state occurred with a mean time constant of 4.7 months, followed by a transition to fast phenotypes by 17.0 months. Conversely, Talmadge et al. reported increased MHC IIx expression by 6 weeks, whereas measurable hybrid MHCs were not observed until 24 weeks [32]. Further, SERCA protein isoforms began to adapt quickly but continued to transform gradually over time, resulting in within-fiber mismatches between SERCA and MHC isoforms [19].

The physiological impact of these biochemical changes remains uncertain. Many questions persist about the biochemical basis of fatigue, contractile speed, force potentiation, and other phenomena, limiting the inferences that may be made between observed biochemical and physiological adaptations to SCI. At present, research is focusing on characterizing timelines for both types of adaptations. Definitive timelines for muscle protein adaptation are not yet fully understood in humans after SCI. Timelines for physiological mechanical changes are better characterized. The electrically elicited torque in recently paralyzed muscle ( $<6$ weeks) is quite low, reflecting the complete loss of muscle activity before segmental reflexes recover [11]. By 6 months post-SCI, a slight increase in torque may be 
observed despite the persistence of profound muscle atrophy [11]. We have previously suggested that connective tissue extensibility may decrease after SCI, which acts to "take up the slack" in the musculotendinous unit, allowing the atrophied muscle to function on a different part of the length-tension curve [11]. Peak torques can only be maintained for a few contractions, however, and fatigue rapidly ensues. In the soleus muscle, fatigue index, a measure of muscle endurance, declines rapidly over the first year and afterward experiences minimal further declines [33]. Eventually, chronically paralyzed ( $>2$ years) soleus muscle generates only 20 to 30 percent of the initial peak torque after a bout of repetitive activation [34]. Thus, chronically paralyzed muscle is unable to generate high repetitive loads and deliver high repetitive stress to bone.

\section{MUSCLE RESPONSE TO TRAINING}

In addition to responding to reduced use (as a result of SCI), muscle contractile, metabolic, and histochemical properties have been observed to adapt to chronically increased muscle activation, in particular, electrical muscle stimulation. Low-resistance electrically stimulated cycling [28,35-36] and isometric training of the quadriceps [37] and the tibialis anterior [30] have shown that paralyzed human muscle adapts to increased use via hypertrophy and improvements in fatigue resistance. Just 8 weeks of cycling increased average vastus lateralis fiber area 23 percent and capillary number 39 percent [23]. Hypertrophy of stimulated muscles has readily been observed after both short-duration [38-39] and long-duration [40] electrical stimulation protocols. One year of cycle training elicited a 12 percent increase in whole-muscle cross-sectional area of the thigh, as well as a shift away from fast-fatigable myosin and toward fast fatigue-resistant myosin [36]. Sixteen weeks of training in people with acute SCI led to partial preservation of type I fiber content and MHC I composition, as well as full preservation of fiber crosssectional area [41]. Oxidative capacity [30,42-43] and glycolytic capacity [44] have also been shown to improve after training, often in the absence of fiber type alterations [42]. Even after brief periods of training, calcium dynamics in paralyzed muscle may begin to adapt [35]. These findings are consistent with animal studies, which have demonstrated that electrical stimulation (in concert with loading) prevents atrophy [45] and may prevent muscle fiber transformation $[27,46]$.
Numerous studies have suggested that the dramatic training effects observed in electrically stimulated paralyzed muscle largely depend on the stimulation parameters used. Low-frequency $(10 \mathrm{~Hz})$ but not high-frequency $(50 \mathrm{~Hz})$ stimulation led to increased fatigue resistance of the quadriceps muscle [42]. High-frequency stimulation is known to compromise neuromuscular transmission (a depletion of neurotransmitters at the neuromuscular junction) and therefore it does not adequately challenge other processes known to affect fatigue, notably excitationcontraction coupling [11]. Repetitive stimulation in muscle's normal physiological frequency range $(15-50 \mathrm{~Hz}$ [47]) may offer a better stimulus for adaptation of muscle fatigue resistance.

The load developed during electrically elicited contractions also affects the magnitude of training-related changes. In wrist extensors trained via either high or low resistance, only high-resistance training yielded fatigue benefits and evidence of metabolic adaptation (as measured by phosphocreatine recovery) [48]. Muscles trained with low loads displayed only small increases [36] or no change $[30,35]$ in cross-sectional area. Most tellingly, quadriceps muscles trained with high load experienced significantly greater improvements in force, type 1 fiber composition, fiber cross-sectional area, capillary-to-fiber ratio, relative oxygenation, and citrate synthase activity than muscles trained with minimal load [49]. Thus, paralyzed muscle continues to adapt according to principles of physical stress [50], in a manner reminiscent of neurologically intact muscle.

Long-duration ( $>8$ hours a day) electrical stimulation causes muscle transformation from fast fatigable to slow or fatigue-resistant muscle properties [51-54]. While 8 hours or more of electrical stimulation is feasible to maximize the muscle "effect" in an animal model, it is not feasible in paralyzed human lower limbs. Over the past several years, our laboratory has investigated an electrical stimulation protocol designed to elicit muscle adaptation while remaining feasible for human use [11,14,34,55-56]. The protocol uses $15 \mathrm{~Hz}$ isometric muscle activation to induce hypertrophy and fatigue-related changes in paralyzed soleus muscle. Subjects performed the majority of stimulation at home using portable stimulators, joint constraint devices, and a compliance monitor. This protocol took roughly 30 minutes a day, and subjects were able to integrate it into their daily routines during a 3-year longitudinal study. (Mean compliance with exercise recommendations was $\sim 80 \%$ over the course of the study.) For 
each subject, one soleus muscle underwent training while the other remained as an untrained within-subject control. In subjects with chronic SCI (>2 years), we demonstrated that repetitive electrical stimulation of the soleus muscle in humans partially reverses the loss of torque and fatigue resistance after SCI [34]. In subjects who began training within 6 weeks post-SCI, torque and fatigue properties could be preserved for more than 3 years, while untrained limbs experienced the expected declines over time [11]. At the end of the protocol, trained limbs generated nearly 100 percent more torque than untrained limbs at the end of a fatigue-inducing stimulation bout. Untrained limbs displayed considerable postactivation potentiation of torque, a hallmark of excitation-contraction compromise [56]. Trained limbs demonstrated almost no potentiation, suggesting that training triggered adaptations within the excitation-contraction system.

As can be seen in Figure 1, 3 years of stimulation with this protocol yielded hypertrophy of the trained soleus muscle. The gastrocnemius, which received electrical current but no loading (the knee was bent during stimulation, placing the gastrocnemius “on slack”), did not display a similar training effect. This finding supports the contention that load, not just activation, is a key factor triggering hypertrophy. Consistent with this premise, the deep flexors of the calf (tibialis anterior, flexor hallicus

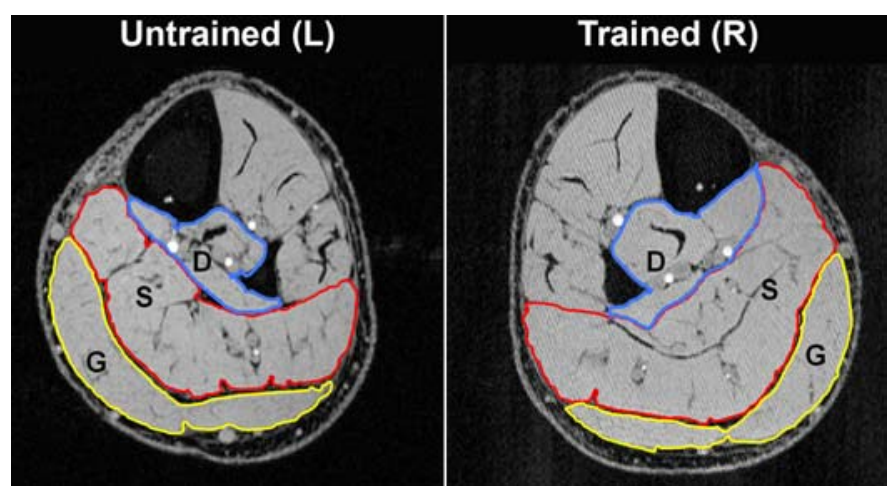

Figure 1.

Magnetic resonance imaging of subject who performed $>3$ years of soleus electrical stimulation training. In stack of 20 such images, trained soleus was substantially larger ( 28\%) than untrained soleus ("S” labels in image). Gastrocnemius area ("G”) did not appreciably differ between limbs. Because gastrocnemius is placed on slack during training in knee-bent position, it received electrical current but little isometric loading. Note that all single-joint muscles in deep posterior compartment ("D") also hypertrophied (tibialis posterior, flexor hallicus longus, flexor digitorum longus). $\mathrm{L}=$ left, $\mathrm{R}=$ right. longus, flexor digitorum longus) demonstrated the most profound training effect (33\% and 36\% for trained and untrained, respectively). As single-joint muscles (similar to the soleus), the deep flexors developed substantial isometric loading. This finding again underscores the critical importance of muscular overload during therapeutic electrical stimulation. However, we urge rehabilitation specialists to remember that these high muscle forces transmit high loads to bones in the paralyzed limbs; the bones of individuals with chronic paralysis are at an increased risk of fracture from disuse-related osteoporosis. For this reason, establishing the optimal dose of physiological stress required to prevent musculoskeletal deterioration early after SCI will become an even more critical priority as spinal cord regenerative cures emerge. With a complete understanding of the adaptive capabilities of paralyzed muscle and dose-response guidelines, we will be better prepared to design functional electrical stimulation protocols that yield the optimal muscle strength and endurance adaptations required for therapeutic loading of bone.

\section{BONE ADAPTATIONS TO SCI}

As just described, skeletal muscle becomes highly fatigable and atrophied after SCI, with limited functional usefulness for standing [57-60], grasping [59,61], or ambulating [59,62-63]. Because muscle is the primary deliverer of loads to the skeletal system [64], the bones of paralyzed limbs lack an important stimulus for maintenance of bone density. Post-SCI osteoporosis has a multifactorial pathophysiology; however, the diminution of mechanical stimuli to bone is considered a powerful contributor to bone demineralization [65-66]. At the lowest end of the activity spectrum, when weight-bearing and muscular contraction diminish or cease after SCI, the loss of mechanical loading yields an imbalance between osteoclastic and osteoblastic activity. Bone resorption outpaces bone formation, eventually yielding neurogenic osteoporosis.

Complete unloading of the limbs, such as in SCI, yields bone loss that is 5 to 20 times greater than losses from purely metabolic etiologies [67]. Within the first few months after SCI, bone mineral density (BMD) begins to decline 2 to 4 percent a month [3], particularly at sites rich in trabecular bone [68]. This decline usually continues for 2 to 8 years (depending on the anatomical site and the method of measurement) [10], eventually 
reaching steady state values 50 to 60 percent lower than non-SCI values $[10,12]$. One small study of monozygotic twins conversely suggests that bone loss may continue over the life span of people with SCI [69]. Trabeculae in the epiphyses become fewer in number [70-71] or may become perforated [72]. Disuse remodeling gradually replaces the trabecular lattice with fatty marrow until, with long-term SCI, very few trabeculae survive in the epiphysis [12]. This extensive destruction of the trabecular lattice is likely to be irreversible [73]. In predominantly cortical regions such as long bone diaphyses, BMD declines only minimally [68]. Instead, bone mass at these sites is lost via thinning of the cortical wall $[10,74]$, which reduces the bone's bending stiffness by as much as 33 percent [75]. The thinness of the diaphyseal cortical wall severely reduces overall bone strength, typically estimated by the second moment of inertia of the cortical shell or by a BMD-normalized stress-strain index [76-79].

As primary sites of demineralization after SCI, the tibia and femur epiphyses $[10,12]$ are also primary sites for fracture [80-83]. Between 1 and 6 percent of people with SCI will sustain fractures in their paralyzed limbs [84-86]. This estimate may be low because sensory impairment in SCI may prevent fractures from being detected and reported $[4,84-86]$. The fracture risk for people with SCI is approximately double the risk for the non-SCI population [87]. The BMD level at which fracture risk increases is not known with certainty. However, Eser and coauthors reported that fractures occurred in subjects with BMD less than 46 and 29 percent of non-SCI norms for the distal femur and distal tibia, respectively [83]. Up to 44 percent of reported fractures occur with minimal inciting trauma [85]. Fractures commonly occur during routine, necessary activities of daily living, such as dressing, bathing, and transferring to and from a wheelchair. Medical management of post-SCI fractures is complicated by anesthetic skin; cast fixation carries an elevated risk of causing pressure ulcers. Open reduction and internal fixation are therefore frequently required, with the attendant risks of surgery and anesthesia.

\section{BONE RESPONSE TO TRAINING}

According to Wolff's hypotheses [88-89] (later refined by Frost [90-93] and Lanyon [94]), bone is in a state of activity-dependent flux and biomechanical stresses have a powerful influence on the structural properties of the skeletal system. Loads applied to bone create an internal resistance called stress that is equal in magnitude and opposite in direction to the applied load [95]. The geometric deformation of bone in response to applied stress is called strain [66], defined quantitatively as the change in length as a percentage of the unloaded length. Strains due to normal activity generally range from 200 to 2,500 $\mu$ strain [96] and the ultimate strength (fracture threshold) of healthy, young lamellar bone is approximately 25,000 $\mu$ strain (equal to $2.5 \%$ change in length) [93], leaving a sizable safety margin for volitional activities. Strains of about 1,500 to 2,500 $\mu$ strain trigger the mobilization of osteoclast and osteoblast drifts at bone surfaces (a process called modeling [90]), leading to enhancements in cortical thickness [78,97-100] and (to a lesser degree) trabecular BMD [78,97,99]. Routine strain levels that are very low (100-300 $\mu$ strain) induce bone loss [101] via a process called remodeling [90]. Remodeling removes more bone mineral via osteoclast activity than it replaces via osteoblast activity. Because remodeling occurs on bone surfaces that are in contact with marrow [102], adaptations to disuse appear at the endosteal surface and the trabecular lattice. This process is clearly exemplified by the disuse-related deterioration of trabecular bone and cortical thinning after SCI.

Animal studies have amply demonstrated the adaptive capacity of bone in response to mechanical loading. Torsional loads [103], impact loading [104], and compressive loads [103,105] have all elicited bone anabolism in animal models. Protocols using external compressive loading of the rat or mouse ulna have explored the roles of strain magnitude [106-107], strain rate [108], and loading bout frequency and duration [109]. In general, bone formation exhibits a positive dose-response relationship with peak strain magnitude [106-107,110-111]. However, peak strains need only approximate the high end of physiological values (rather than be excessive) to trigger bone formation [106-107]. Short, frequent loading bouts [109] conducted at a high strain rate [108] show particular osteogenic potential. Some authors have theorized that bone most vigorously responds to the "errorrich" components of the loading environment [65]; therefore, even small strains may engender an osteogenic response if they are presented at a strain rate, distribution, frequency, or duration that is novel within the bone's loading milieu [112-113]. 
For simulation of SCI, animal models of limb unloading have been developed, including hind limb unloading [114-116] and the functionally isolated avian ulna [103]. Animal models of SCI (contusion, transection) that examine bone loss are less common because of various degrees of spontaneous recovery and the uncertainty of unloading muscle and bone in many species [117-120]). In both the rat and avian non-SCI models, the pattern of bone loss (rapid demineralization of trabecular bone, endosteal absorption of cortical bone) resembles the trends observed in human long bones after SCI. Importantly, small doses of load interspersed within prolonged unloading protocols appear sufficient to preserve BMD in both avian and rodent models $[103,121]$. These results support the potential usefulness of reintroduction of load after disuserelated BMD loss.

In humans with SCI, the search for an efficacious method for preserving or improving BMD after SCI has been fraught with difficulty. Previous dual-energy X-ray absorptiometry (DEXA)-based studies of passive standing [122], standing with low-level electrical stimulation [123-124], and electrically stimulated cycling [125-126] revealed no BMD effects due to resumption of loading. Trabecular bone, which is more metabolically active than cortical bone [127], would be expected to respond readily to the loading stimulus. Because DEXA cannot differentiate between cortical and trabecular bone, trabecular adaptations may have been overlooked, if they did indeed occur. On the other hand, mechanical loads delivered during these studies may have been insufficient to exceed bone's remodeling threshold (loads were not quantified in these studies). Bloomfield and colleagues' investigation of electrically stimulated cycling revealed a similar lack of responsiveness in the majority of subjects who trained at a low work output [128]. However, a subset of subjects who worked at a higher intensity (and ostensibly, a higher mechanical load) showed small BMD increases at the distal femur, a predominantly trabecular site. Mohr and colleagues showed that subjects with SCI who substantially increased their cycling work capacity over 1 year experienced a small (10\%) increase in BMD at the proximal tibia, another trabecular region [129]. Again, without quantification of mechanical loads or separate analysis of trabecular bone, whether the cycling intervention induced trabecular anabolism that remained hidden or whether loads in previous studies simply were subthreshold is unclear.
Three-dimensional densitometric techniques (such as peripheral quantitative computed tomography [pQCT]) can clarify the differential responses of trabecular and cortical bone to restoration of loading after SCI. Recent work from our laboratory shows that trabecular bone vigorously responds to the reintroduction of physiological mechanical load after SCI [11]. Subjects with SCI completed up to 3 years of unilateral soleus electrical stimulation training. Compressive loads delivered to the tibia via muscle contraction were approximately 1.5 times body weight. At the end of the study, pQCT revealed that trabecular BMD at the distal tibia was 31 percent higher in trained limbs than in untrained limbs (Figure 2) [11]. No

(a)

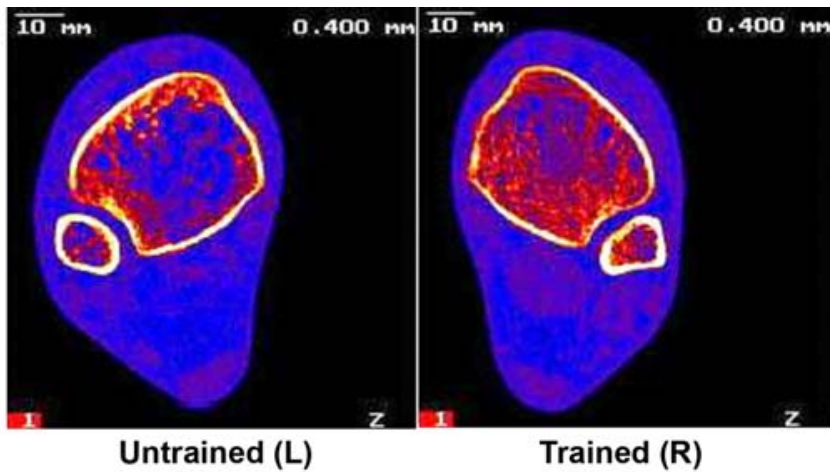

(b)

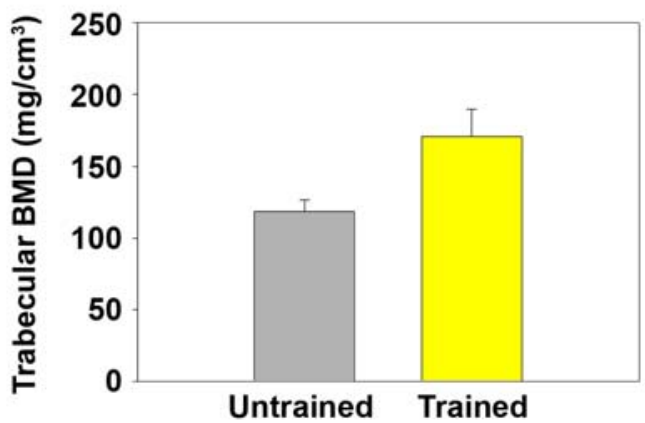

Figure 2.

(a) Peripheral quantitative computed tomography (pQCT) imaging of distal tibia of same subject in Figure 1. (Image is viewed from cephalad rather than caudad direction. In this subject, right leg underwent training.) Note extensive loss of trabecular lattice in untrained limb. $\mathrm{L}=$ left, $\mathrm{R}=$ right. (b) Distal tibia trabecular bone mineral density (BMD) for 3 subjects who trained $>3$ years was $30 \%$ higher in trained than untrained limbs $(p<0.05)$. Typical non-spinal cord injury BMD at this site is $250 \mathrm{mg} / \mathrm{cm}^{3}$. Source: Eser P, Frotzler A, Zehnder Y, Wick L, Knecht H, Denoth J, Schiessl H. Relationship between the duration of paralysis and bone structure: A pQCT study of spinal cord injured individuals. Bone. 2004;34(5):869-80 [PMID: 15121019]; Shields RK, Dudley-Javoroski S, Boaldin KM, Corey TA, Fog DB, Ruen JM. Peripheral quantitative computed tomography: Measurement sensitivity in persons with and without spinal cord injury. Arch Phys Med Rehabil. 2006;87(10):1376-81. [PMID: 17023249] 
BMD difference was apparent in cortical bone, in accordance with previous studies [68]. Sites that experienced no mechanical loading (hips and untrained tibia) experienced the expected degree of post-SCI demineralization $[11,130]$. These results underscore the importance of dose of loading in protocols designed to address bone demineralization after SCI. A physiological magnitude of load, delivered in a manner that subjects could administer independently, was useful for attenuating the normally occurring decline in bone density. Additional studies are underway in our laboratory to determine the optimal loading conditions for preserving bone density in the entire paralyzed lower limb.

The precise combination of mechanical stimuli required to elicit bone adaptation is unknown. Because the cellular and molecular responses to mechanical stimulation are incompletely understood, numerous modes of input remain viable candidates for osteoregulatory signals. First, as related in the previous section, the maximal strains in a bone's loading milieu may trigger anabolism (in athletes, for instance) or catabolism (as in SCI). Support exists for this viewpoint at both ends of the loading continuum [83,131]. Other researchers, however, point out that low-intensity and usually imperceptible vibratory loads predominate bone's daily strain history [132]. Thus, in the absence of postural contractions after SCI, neurogenic osteoporosis may develop because pervasive lowmagnitude strains are lost, rather than because a few large strains each day are absent. This hypothesis is supported by the finding that routine postural contractions in the 30 to $50 \mathrm{~Hz}$ range decline in older adults (both sexes) [47], a group that undergoes serious bone demineralization over time. In our laboratory, we are investigating the reintroduction of low-magnitude mechanical signals (vibration) as a way to preserve BMD after SCI.

\section{NEURAL CONTRIBUTIONS TO MUSCULOSKELETAL DETERIORATION}

While we generally understand the role of mechanical loading (compression and vibration) in paralyzed bone, we know very little about the effects of lost neural connectivity to the musculoskeletal system. Bone has an extensive sympathetic and sensory nerve supply, particularly in metabolically active regions [133]. These nerve fibers may sense local mechanical loads [134] or may stimulate bone remodeling via several locally acting neuropeptides [135136]. Because sympathetic adrenergic nerves accompany intraosseous blood vessels, bone's nerve supply may also allow communication between the autonomic and skeletal systems [137]. The disruption of sympathetic nerve activity after SCI exerts an unknown influence on bone. Although a link between autonomic disruption, intramedullary venous stasis, and osteoporosis has been hypothesized [138-139], it has not been rigorously studied. Clinically, disruptions of neural input (and likely the accompanying vascular derangements) have been seen to positively and negatively affect bone mineralization, as in Charcot neuropathy and in exuberant callus formation in people with head injuries and limb fractures [137]. In SCI, however, a dearth of knowledge exists about the effects of lost neural connectivity independent from the influence of lost mechanical loading. Whether therapeutic electrical muscle stimulation, compressive loading, and/or vibration training induce training effects upon bone via neural and not just mechanical processes remains to be seen.

The reciprocal interactions between the paralyzed nervous and muscular systems are much more thoroughly understood. After SCI, if lower motor neuron injury does not occur, the spinal circuits, peripheral nerves, and muscles below the level of injury retain their normal connections. New evidence suggests that neuromuscular activity at one link of this chain can strongly influence other connected components, even in the absence of supraspinal control. In response to cycling exercise, rat soleus muscles up-regulated the expression of brain-derived neurotrophic factor (BDNF) and glial cell line-derived neurotrophic factor (GDNF) [140]. During development, GDNF is a motor neuron survival factor [141]. In the adult nervous system, BDNF may foster neuromuscular connectivity as well as have a role in neuroprotection and regeneration [142]. Both BDNF and GDNF are transported retrogradely from the periphery to the spinal cord, as is neurotrophin 3 (NT-3) [143], another promoter of spinal cell proliferation and survival [144]. NT-3 expression is also modulated by exercise in the spinalized rat [145].

Although post-SCI exercise appears to yield a retrograde effect on spinal circuitry, the physiological manifestation of this effect remains uncertain. In the non-SCI model, various modes of exercise clearly influence monosynaptic reflex pathways [146-147]. Various studies of monosynaptic spinal reflexes after SCI suggest that shortand long-term training regimens may partially restore normal suppression of $\mathrm{H}$ reflexes. Three months of hind limb cycling led to restoration of $\mathrm{H}$ reflex suppression in spinal 
rats [148]. In a single human subject with incomplete SCI, 4 months of treadmill ambulation yielded $\mathrm{H}$ reflex suppression values nearer to nondisabled values than before training [149]. Most recently, our laboratory demonstrated that 2 years of unilateral soleus electrical stimulation led to a moderate shift toward normal $\mathrm{H}$ reflex suppression values in trained limbs, while untrained limbs demonstrated a highly variable and unpredictable pattern of suppression.

\section{SUMMARY AND CONCLUSIONS}

An important goal for rehabilitation specialists in the next decade will be to minimize the deleterious metabolic chaos that results from the immediate and extensive loss of stress to the musculoskeletal system after SCI. Scientifically grounded therapeutic interventions that quantify the dose of stress required to sustain musculoskeletal integrity will need to advance in step with spinal cord regeneration studies. New electrical stimulation technologies designed to capitalize on the extensive plasticity of paralyzed muscle and bone must emerge. However, these technologies must be feasible so that the individual with SCI can comply with a prescribed dose of stress. Homebased stimulation systems that allow subjects to integrate frequent training into their daily lives appear important as we translate knowledge about post-SCI musculoskeletal plasticity.

\section{ACKNOWLEDGMENTS}

We thank Dan Thedens, PhD; Daniel J. Schiferl; Deanna Frei, RT (R) (CT) (BD), CDT; and April Miller, RT (R), CDT, for their technical expertise.

This material was based on work supported by the National Institutes of Health (grant R01 NR-010285-05 to Richard K. Shields), the Christopher Reeve Paralysis Foundation (to Richard K. Shields), and the Foundation for Physical Therapy, Inc (scholarship to Shauna DudleyJavoroski).

The authors have declared that no competing interests exist.

*Shields RK, unpublished observations, 2004.

\section{REFERENCES}

1. Stover SL, DeLisa JA, Whiteneck GG. Spinal cord injury: Clinical outcomes from the model systems. Gaithersburg (MD): Aspen Publishers, Inc; 1995.

2. Shields RK, Dudley-Javoroski S. Musculoskeletal deterioration and hemicorporectomy after spinal cord injury. Phys Ther. 2003;83(3):263-75. [PMID: 12620090]

3. Wilmet E, Ismail AA, Heilporn A, Welraeds D, Bergmann P. Longitudinal study of the bone mineral content and of soft tissue composition after spinal cord section. Paraplegia. 1995;33(11):674-77. [PMID: 8584304]

4. Abramson AS. Bone disturbances in injuries to the spinal cord and cauda equina (paraplegia). J Bone Joint Surg. 1948;30:982-87.

5. Claus-Walker J, Carter RE, Campos RJ, Spencer WA. Sitting, muscular exercises, and collagen metabolism in tetraplegia. Am J Phys Med. 1979;58(6):285-93. [PMID: 517641]

6. Issekutz B Jr, Blizzard JJ, Birkhead NC, Rodahl K. Effect of prolonged bed rest on urinary calcium output. J Appl Physiol. 1966;21(3):1013-20. [PMID: 5912717]

7. Kaplan PE, Roden W, Gilbert E, Richards L, Goldschmidt JW. Reduction of hypercalciuria in tetraplegia after weight-bearing and strengthening exercises. Paraplegia. 1981;19(5):289-93. [PMID: 7279431]

8. Bigland-Ritchie B, Woods JJ. Changes in muscle contractile properties and neural control during human muscular fatigue. Muscle Nerve. 1984;7(9):691-99. [PMID: 6100456]

9. Freeman LW. The metabolism of calcium in patients with spinal cord injuries. Ann Surg. 1949;129(2):177-84. [PMID: 18108615]

10. Eser P, Frotzler A, Zehnder Y, Wick L, Knecht H, Denoth J, Schiessl H. Relationship between the duration of paralysis and bone structure: A pQCT study of spinal cord injured individuals. Bone. 2004;34(5):869-80. [PMID: 15121019]

11. Shields RK, Dudley-Javoroski S. Musculoskeletal plasticity after acute spinal cord injury: Effects of long-term neuromuscular electrical stimulation training. J Neurophysiol. 2006;95(4):2380-90. [PMID: 16407424]

12. Shields RK, Dudley-Javoroski S, Boaldin KM, Corey TA, Fog DB, Ruen JM. Peripheral quantitative computed tomography: Measurement sensitivity in persons with and without spinal cord injury. Arch Phys Med Rehabil. 2006; 87(10):1376-81. [PMID: 17023249]

13. Keating JF, Kerr M, Delargy M. Minimal trauma causing fractures in patients with spinal cord injury. Disabil Rehabil. 1992;14(2):108-9. [PMID: 1600181]

14. Shields RK. Fatigability, relaxation properties, and electromyographic responses of the human paralyzed soleus muscle. J Neurophysiol. 1995;73(6):2195-2206.

[PMID: 7666132] 
15. Shields RK, Law LF, Reiling B, Sass K, Wilwert J. Effects of electrically induced fatigue on the twitch and tetanus of paralyzed soleus muscle in humans. J Appl Physiol. 1997;82(5):1499-1507. [PMID: 9134899]

16. Burnham R, Martin T, Stein R, Bell G, MacLean I, Steadward R. Skeletal muscle fibre type transformation following spinal cord injury. Spinal Cord. 1997;35(2):86-91. [PMID: 9044514]

17. Gerrits HL, De Haan A, Hopman MT, Van Der Woude LH, Jones DA, Sargeant AJ. Contractile properties of the quadriceps muscle in individuals with spinal cord injury. Muscle Nerve. 1999;22(9):1249-56. [PMID: 10454722]

18. Talmadge RJ, Roy RR, Caiozzo VJ, Edgerton VR. Mechanical properties of rat soleus after long-term spinal cord transection. J Appl Physiol. 2002;93(4):1487-97. [PMID: 12235051$]$

19. Talmadge RJ, Castro MJ, Apple DF Jr, Dudley GA. Phenotypic adaptations in human muscle fibers 6 and 24 wk after spinal cord injury. J Appl Physiol. 2002;92(1):147-54. [PMID: 11744654]

20. Round JM, Barr FM, Moffat B, Jones DA. Fibre areas and histochemical fibre types in the quadriceps muscle of paraplegic subjects. J Neurol Sci. 1993;116(2):207-11. [PMID: 8336167]

21. Grimby G, Broberg C, Krotkiewska I, Krotkiewski M. Muscle fiber composition in patients with traumatic cord lesion. Scand J Rehabil Med. 1976;8(1):37-42. [PMID: 132700]

22. Scelsi R, Marchetti C, Poggi P, Lotta S, Lommi G. Muscle fiber type morphology and distribution in paraplegic patients with traumatic cord lesion. Histochemical and ultrastructural aspects of rectus femoris muscle. Acta Neuropathol. 1982;57(4):243-48. [PMID: 7136501]

23. Chilibeck PD, Jeon J, Weiss C, Bell G, Burnham R. Histochemical changes in muscle of individuals with spinal cord injury following functional electrical stimulated exercise training. Spinal Cord. 1999;37:264-68. [PMID: 10338346]

24. Otis JS, Roy RR, Edgerton VR, Talmadge RJ. Adaptations in metabolic capacity of rat soleus after paralysis. J Appl Physiol. 2004;96(2):584-96. [PMID: 14565962]

25. Castro MJ, Apple DF Jr, Staron RS, Campos GE, Dudley GA. Influence of complete spinal cord injury on skeletal muscle within 6 mo of injury. J Appl Physiol. 1999;86(1): 350-58. [PMID: 9887150]

26. Talmadge RJ, Roy RR, Edgerton VR. Persistence of hybrid fibers in rat soleus after spinal cord transection. Anat Rec. 1999;255(2):188-201. [PMID: 10359520]

27. Roy RR, Talmadge RJ, Hodgson JA, Zhong H, Baldwin KM, Edgerton VR. Training effects on soleus of cats spinal cord transected (T12-13) as adults. Muscle Nerve. 1998;21(1):63-71. [PMID: 9427225]
28. Andersen JL, Mohr T, Biering-Sorensen F, Galbo H, Kjaer M. Myosin heavy chain isoform transformation in single fibres from $\mathrm{m}$. vastus lateralis in spinal cord injured individuals: Effects of long-term functional electrical stimulation (FES). Pflugers Arch. 1996;431(4):513-18. [PMID: 8596693]

29. Lieber RL, Friden JO, Hargens AR, Feringa ER. Longterm effects of spinal cord transection on fast and slow rat skeletal muscle. II. Morphometric properties. Exp Neurol. 1986;91(3):435-48. [PMID: 2936616]

30. Martin TP, Stein RB, Hoeppner PH, Reid DC. Influence of electrical stimulation on the morphological and metabolic properties of paralyzed muscle. J Appl Physiol. 1992; 72(4):1401-6. [PMID: 1534322]

31. Castro MJ, Apple DF Jr, Hillegass EA, Dudley GA. Influence of complete spinal cord injury on skeletal muscle cross-sectional area within the first 6 months of injury. Eur J Appl Physiol Occup Physiol. 1999;80(4):373-78. [PMID: 10483809]

32. Talmadge RJ. Myosin heavy chain isoform expression following reduced neuromuscular activity: Potential regulatory mechanisms. Muscle Nerve. 2000;23(5):661-79. [PMID: 10797389]

33. Shields RK, Chang YJ, Dudley-Javoroski S, Lin CH. Predictive model of muscle fatigue after spinal cord injury in humans. Muscle Nerve. 2006;34(1):84-91.

[PMID: 16634064]

34. Shields RK, Dudley-Javoroski S. Musculoskeletal adaptation in chronic spinal cord injury: Effects of long-term soleus electrical stimulation training. J Neurorehabil Neural Repair. 2007;21(2):169-79. [PMID: 17312092]

35. Gerrits HL, de Haan A, Sargeant AJ, Dallmeijer A, Hopman MT. Altered contractile properties of the quadriceps muscle in people with spinal cord injury following functional electrical stimulated cycle training. Spinal Cord. 2000;38(4):214-23. [PMID: 10822391]

36. Mohr T, Andersen JL, Biering-Sorensen F, Galbo $\mathrm{H}$, Bangsbo J, Wagner A, Kjaer M. Long-term adaptation to electrically induced cycle training in severe spinal cord injured individuals. Spinal Cord. 1997;35(1):1-16.

[PMID: 9025213] Erratum in: Spinal Cord. 1997;35(4):262.

37. Gerrits HL, Hopman MT, Sargeant AJ, Jones DA, De Haan A. Effects of training on contractile properties of paralyzed quadriceps muscle. Muscle Nerve. 2002;25(4): 559-67. [PMID: 11932974]

38. Hjeltnes N, Aksnes AK, Birkeland KI, Johansen J, Lannem A, Wallberg-Henriksson $\mathrm{H}$. Improved body composition after 8 wk of electrically stimulated leg cycling in tetraplegic patients. Am J Physiol. 1997;273(3 Pt 2):R1072-79. [PMID: 9321888]

39. Mahoney ET, Bickel CS, Elder C, Black C, Slade JM, Apple DR Jr, Dudley GA. Changes in skeletal muscle size 
and glucose tolerance with electrically stimulated resistance training in subjects with chronic spinal cord injury. Arch Phys Med Rehabil. 2005;86(7):1502-4.

[PMID: 16003691]

40. Dudley GA, Castro MJ, Rogers S, Apple DF Jr. A simple means of increasing muscle size after spinal cord injury: A pilot study. Eur J Appl Physiol Occup Physiol. 1999; 80(4):394-96. [PMID: 10483812]

41. Crameri RM, Weston AR, Rutkowski S, Middleton JW, Davis GM, Sutton JR. Effects of electrical stimulation leg training during the acute phase of spinal cord injury: A pilot study. Eur J Appl Physiol. 2000;83(4-3):409-15. [PMID: 11138583]

42. Gerrits HL, Hopman MT, Offringa C, Engelen BG, Sargeant AJ, Jones DA, Haan A. Variability in fibre properties in paralysed human quadriceps muscles and effects of training. Pflugers Arch. 2003;445(6):734-40.

[PMID: 12632195]

43. Crameri RM, Weston A, Climstein M, Davis GM, Sutton JR. Effects of electrical stimulation-induced leg training on skeletal muscle adaptability in spinal cord injury. Scand J Med Sci Sports. 2002;12(5):316-22. [PMID: 12383078]

44. Kjaer M, Mohr T, Biering-Sorensen F, Bangsbo J. Muscle enzyme adaptation to training and tapering-off in spinalcord-injured humans. Eur J Appl Physiol. 2001;84(5): 482-86. [PMID: 11417439]

45. Dupont-Versteegden EE, Houle JD, Gurley CM, Peterson CA. Early changes in muscle fiber size and gene expression in response to spinal cord transection and exercise. Am J Physiol. 1998;275(4 Pt 1):C1124-33. [PMID: 9755066]

46. Roy RR, Zhong H, Hodgson JA, Grossman EJ, Siengthai $\mathrm{B}$, Talmadge RJ, Edgerton VR. Influences of electromechanical events in defining skeletal muscle properties. Muscle Nerve. 2002;26(2):238-51. [PMID: 12210389]

47. Huang RP, Rubin CT, McLeod KJ. Changes in postural muscle dynamics as a function of age. J Gerontol A Biol Sci Med Sci. 1999;54(8):B352-57. [PMID: 10496541$]$

48. Hartkopp A, Harridge SD, Mizuno M, Ratkevicius A, Quistorff B, Kjaer M, Biering-Sorensen F. Effect of training on contractile and metabolic properties of wrist extensors in spinal cord-injured individuals. Muscle Nerve. 2003;27(1):72-80. [PMID: 12508298]

49. Crameri RM, Cooper P, Sinclair PJ, Bryant G, Weston A. Effect of load during electrical stimulation training in spinal cord injury. Muscle Nerve. 2004;29(1):104-11. [PMID: 14694505]

50. Mueller MJ, Maluf KS. Tissue adaptation to physical stress: A proposed "Physical Stress Theory" to guide physical therapist practice, education, and research. Phys Ther. 2002;82(4):383-403. [PMID: 11922854]

51. Brown WE, Salmons S, Whalen RG. The sequential replacement of myosin subunit isoforms during muscle type transformation induced by long term electrical stimulation. J Biol Chem. 1983;258(23):14686-92. [PMID: 6643504]

52. Gordon T, Tyreman N, Rafuse VF, Munson JB. Fast-toslow conversion following chronic low-frequency activation of medial gastrocnemius muscle in cats. I. Muscle and motor unit properties. J Neurophysiol. 1997;77(5): 2585-2604. [PMID: 9163378]

53. Salmons S, Sreter FA. Significance of impulse activity in the transformation of skeletal muscle type. Nature. 1976; 263(5572):30-34. [PMID: 958462]

54. Sutherland H, Jarvis JC, Kwende MM, Gilroy SJ, Salmons $\mathrm{S}$. The dose-related response of rabbit fast muscle to longterm low-frequency stimulation. Muscle Nerve. 1998; 21(12):1632-46. [PMID: 9843063]

55. Shields RK, Dudley-Javoroski S, Cole KR. Feedbackcontrolled stimulation enhances human paralyzed muscle performance. J Appl Physiol. 2006;101(5):1312-19. [PMID: 16809630]

56. Shields RK, Dudley-Javoroski S, Littmann AE. Postfatigue potentiation of paralyzed soleus muscle: Evidence for adaptation with long-term electrical stimulation training. J Appl Physiol. 2006;101(2):556-65. [PMID: 16575026]

57. Cybulski GR, Penn RD, Jaeger RJ. Lower extremity functional neuromuscular stimulation in cases of spinal cord injury. Neurosurgery. 1984;15(1):132-46. [PMID: 6382044]

58. Jaeger RJ. Lower extremity applications of functional neuromuscular stimulation. Assist Technol. 1992;4(1):19-30. [PMID: 10148013]

59. Yarkony GM, Roth EJ, Cybulski G, Jaeger RJ. Neuromuscular stimulation in spinal cord injury: I: Restoration of functional movement of the extremities. Arch Phys Med Rehabil. 1992;73(1):78-86. [PMID: 1729980]

60. Yarkony GM, Jaeger RJ, Roth E, Kralj AR, Quintern J. Functional neuromuscular stimulation for standing after spinal cord injury. Arch Phys Med Rehabil. 1990;71(3): 201-6. [PMID: 2317138]

61. Billian C, Gorman PH. Upper extremity applications of functional neuromuscular stimulation. Assist Technol. 1992; 4(1):31-39. [PMID: 10171598]

62. Goodship AE, Lanyon LE, McFie H. Functional adaptation of bone to increased stress. An experimental study. J Bone Joint Surg Am. 1979;61(4):539-46. [PMID: 438241]

63. Kralj AR, Bajd T. Functional electrical stimulation. Standing and walking after spinal cord injury. Boca Raton (FL): CRC Press; 1989.

64. Lu TW, Taylor SJ, O’Connor JJ, Walker PS. Influence of muscle activity on the forces in the femur: An in vivo study. J Biomech. 1997;30(11-12):1101-6. [PMID: 9456377]

65. Lanyon LE. Using functional loading to influence bone mass and architecture: Objectives, mechanisms, and relationship with estrogen of the mechanically adaptive process in bone. Bone. 1996;18(1 Suppl):37S-43S. [PMID: 8717546] 
66. Schultheis L. The mechanical control system of bone in weightless spaceflight and in aging. Exp Gerontol. 1991; 26(2-3):203-14. [PMID: 1915691]

67. Mazess RB, Whedon GD. Immobilization and bone. Calcif Tissue Int. 1983;35(3):265-67. [PMID: 6409385]

68. Frey-Rindova P, De Bruin ED, Stussi E, Dambacher MA, Dietz V. Bone mineral density in upper and lower extremities during 12 months after spinal cord injury measured by peripheral quantitative computed tomography. Spinal Cord. 2000;38(1):26-32. [PMID: 10762194$]$

69. Bauman WA, Spungen AM, Wang J, Pierson RN Jr, Schwartz E. Continuous loss of bone during chronic immobilization: A monozygotic twin study. Osteoporos Int. 1999;10(2):123-27. [PMID: 10501792]

70. Slade JM, Bickel CS, Modlesky CM, Majumdar S, Dudley GA. Trabecular bone is more deteriorated in spinal cord injured versus estrogen-free postmenopausal women. Osteoporos Int. 2005;16(5):263-72. [PMID: 15338112]

71. Modlesky CM, Majumdar S, Narasimhan A, Dudley GA. Trabecular bone microarchitecture is deteriorated in men with spinal cord injury. J Bone Miner Res. 2004;19(1): 48-55. [PMID: 14753736]

72. Ciarelli TE, Fyhrie DP, Schaffler MB, Goldstein SA. Variations in three-dimensional cancellous bone architecture of the proximal femur in female hip fractures and in controls. J Bone Miner Res. 2000;15(1):32-40.

[PMID: 10646112]

73. Parfitt AM. Trabecular bone architecture in the pathogenesis and prevention of fracture. Am J Med. 1987;82(1B): 68-72. [PMID: 3544835]

74. Modlesky CM, Slade JM, Bickel CS, Meyer RA, Dudley GA. Deteriorated geometric structure and strength of the midfemur in men with complete spinal cord injury. Bone. 2005;36(2):331-39. [PMID: 15780960]

75. De Bruin ED, Herzog R, Rozendal RH, Michel D, Stussi E. Estimation of geometric properties of cortical bone in spinal cord injury. Arch Phys Med Rehabil. 2000;81(2): 150-56. [PMID: 10668767]

76. Ferretti JL, Capozza RF, Zanchetta JR. Mechanical validation of a tomographic (pQCT) index for noninvasive estimation of rat femur bending strength. Bone. 1996;18(2): 97-102. [PMID: 8833202]

77. Haapasalo H, Kontulainen S, Sievanen H, Kannus P, Jarvinen M, Vuori I. Exercise-induced bone gain is due to enlargement in bone size without a change in volumetric bone density: A peripheral quantitative computed tomography study of the upper arms of male tennis players. Bone. 2000;27(3):351-57. [PMID: 10962345]

78. Kontulainen S, Sievanen H, Kannus P, Pasanen M, Vuori I. Effect of long-term impact-loading on mass, size, and estimated strength of humerus and radius of female racquet-sports players: A peripheral quantitative computed tomography study between young and old starters and controls. J Bone Miner Res. 2003;18(2):352-59.

[PMID: 12568413]

79. Jamsa T, Jalovaara P, Peng Z, Vaananen HK, Tuukkanen J. Comparison of three-point bending test and peripheral quantitative computed tomography analysis in the evaluation of the strength of mouse femur and tibia. Bone. 1998;23(2): 155-61. [PMID: 9701475]

80. Biering-Sorensen F, Bohr HH, Schaadt OP. Longitudinal study of bone mineral content in the lumbar spine, the forearm and the lower extremities after spinal cord injury. Eur J Clin Invest. 1990;20(3):330-35. [PMID: 2114994]

81. Garland DE, Stewart CA, Adkins RH, Hu SS, Rosen C, Liotta FJ, Weinstein DA. Osteoporosis after spinal cord injury. J Orthop Res. 1992;10(3):371-78. [PMID: 1569500]

82. Uebelhart D, Demiaux-Domenech B, Roth M, Chantraine A. Bone metabolism in spinal cord injured individuals and in others who have prolonged immobilisation. A review. Paraplegia. 1995;33(11):669-73. [PMID: 8584303]

83. Eser P, Frotzler A, Zehnder Y, Denoth J. Fracture threshold in the femur and tibia of people with spinal cord injury as determined by peripheral quantitative computed tomography. Arch Phys Med Rehabil. 2005;86(3):498-504. [PMID: 15759235]

84. Ragnarsson KT, Sell GH. Lower extremity fractures after spinal cord injury: A retrospective study. Arch Phys Med Rehabil. 1981;62(9):418-23. [PMID: 7283682]

85. Comarr AE, Hutchinson RH, Bors E. Extremity fractures of patients with spinal cord injuries. Am J Surg. 1962;103: 732-39. [PMID: 13880733]

86. Eichenholtz SN. Management of long-bone fractures in paraplegic patients. J Bone Joint Surg. 1963;45:299-310.

87. Vestergaard P, Krogh K, Rejnmark L, Mosekilde L. Fracture rates and risk factors for fractures in patients with spinal cord injury. Spinal Cord. 1998;36(11):790-96. [PMID: 9848488]

88. Wolff J. Das gesetz der transformation der knochen. Berlin (Germany): Hirschwald; 1892.

89. Wolff J. The law of bone remodeling. New York (NY): Springer-Verlag; 1986.

90. Frost HM. Bone "mass" and the "mechanostat": A proposal. Anat Rec. 1987;219(1):1-9. [PMID: 3688455]

91. Frost HM. Skeletal structural adaptations to mechanical usage (SATMU): 1. Redefining Wolff's law: The bone modeling problem. Anat Rec. 1990;226(4):403-13. [PMID: 2184695]

92. Frost HM. Skeletal structural adaptations to mechanical usage (SATMU): 2. Redefining Wolff's law: The remodeling problem. Anat Rec. 1990;226(4):414-22.

[PMID: 2184696] 
93. Frost HM. Bone's mechanostat: A 2003 update. Anat Rec A Discov Mol Cell Evol Biol. 2003;275(2):1081-1101. [PMID: 14613308]

94. Lanyon LE. Osteocytes, strain detection, bone modeling and remodeling. Calcif Tissue Int. 1993;53 Suppl 1:S102-7. [PMID: 8275362]

95. Ozkaya N, Nordin M. Fundamentals of biomechanics: Equilibrium, motion, and deformation. New York (NY): Springer; 1999.

96. Frost HM. Vital biomechanics: Proposed general concepts for skeletal adaptations to mechanical usage. Calcif Tissue Int. 1988;42(3):145-56. [PMID: 3130163]

97. Heinonen A, Sievanen H, Kyrolainen H, Perttunen J, Kannus P. Mineral mass, size, and estimated mechanical strength of triple jumpers' lower limb. Bone. 2001;29(3): 279-85. [PMID: 11557373]

98. Nikander R, Sievanen H, Heinonen A, Kannus P. Femoral neck structure in adult female athletes subjected to different loading modalities. J Bone Miner Res. 2005;20(3): 520-28. [PMID: 15746998]

99. Heinonen A, Sievanen H, Kannus P, Oja P, Vuori I. Sitespecific skeletal response to long-term weight training seems to be attributable to principal loading modality: A pQCT study of female weightlifters. Calcif Tissue Int. 2002;70(6):469-74. [PMID: 12016461]

100. Kanehisa H, Fukunaga T. Profiles of musculoskeletal development in limbs of college Olympic weightlifters and wrestlers. Eur J Appl Physiol Occup Physiol. 1999; 79(5):414-20. [PMID: 10208250]

101. Mosekilde L. Osteoporosis and exercise. Bone. 1995; 17(3):193-95. [PMID: 8541130]

102. Frost HM. The role of changes in mechanical usage set points in the pathogenesis of osteoporosis. J Bone Miner Res. 1992;7(3):253-61. [PMID: 1585826]

103. Rubin C, Gross T, Qin YX, Fritton S, Guilak F, McLeod $\mathrm{K}$. Differentiation of the bone-tissue remodeling response to axial and torsional loading in the turkey ulna. J Bone Joint Surg Am. 1996;78(10):1523-33. [PMID: 8876580]

104. Jarvinen TL, Kannus P, Sievanen H, Jolma P, Heinonen A, Jarvinen M. Randomized controlled study of effects of sudden impact loading on rat femur. J Bone Miner Res. 1998;13(9):1475-82. [PMID: 9738521]

105. Chow JW, Jagger CJ, Chambers TJ. Characterization of osteogenic response to mechanical stimulation in cancellous bone of rat caudal vertebrae. Am J Physiol. 1993; 265(2 Pt 1):E340-47. [PMID: 8368304]

106. Mosley JR, March BM, Lynch J, Lanyon LE. Strain magnitude related changes in whole bone architecture in growing rats. Bone. 1997;20(3):191-98. [PMID: 9071468]

107. Lee KC, Maxwell A, Lanyon LE. Validation of a technique for studying functional adaptation of the mouse ulna in response to mechanical loading. Bone. 2002;31(3):407-12. [PMID: 12231414]

108. Mosley JR, Lanyon LE. Strain rate as a controlling influence on adaptive modeling in response to dynamic loading of the ulna in growing male rats. Bone. 1998;23(4): 313-18. [PMID: 9763142]

109. Robling AG, Hinant FM, Burr DB, Turner CH. Shorter, more frequent mechanical loading sessions enhance bone mass. Med Sci Sports Exerc. 2002;34(2):196-202. [PMID: 11828225]

110. Hsieh YF, Robling AG, Ambrosius WT, Burr DB, Turner $\mathrm{CH}$. Mechanical loading of diaphyseal bone in vivo: The strain threshold for an osteogenic response varies with location. J Bone Miner Res. 2001;16(12):2291-97. [PMID: 11760844]

111. De Souza RL, Matsuura M, Eckstein F, Rawlinson SC, Lanyon LE, Pitsillides AA. Non-invasive axial loading of mouse tibiae increases cortical bone formation and modifies trabecular organization: A new model to study cortical and cancellous compartments in a single loaded element. Bone. 2005;37(16):810-18. [PMID: 16198164]

112. Rubin C, Judex S, Qin YX. Low-level mechanical signals and their potential as a non-pharmacological intervention for osteoporosis. Age Ageing. 2006;35 Suppl 2:ii32-ii36. [PMID: 16926201]

113. Rubin C, Turner AS, Mallinckrodt C, Jerome C, McLeod $\mathrm{K}$, Bain S. Mechanical strain, induced noninvasively in the high-frequency domain, is anabolic to cancellous bone, but not cortical bone. Bone. 2002;30(3):445-52. [PMID: 11882457]

114. Bloomfield SA, Allen MR, Hogan HA, Delp MD. Siteand compartment-specific changes in bone with hindlimb unloading in mature adult rats. Bone. 2002;31(1):149-57. [PMID: 12110428]

115. Allen MR, Bloomfield SA. Hindlimb unloading has a greater effect on cortical compared with cancellous bone in mature female rats. J Appl Physiol. 2003;94(2):642-50. [PMID: 12391029]

116. David V, Lafage-Proust $\mathrm{MH}$, Laroche N, Christian A, Ruegsegger P, Vico L. Two-week longitudinal survey of bone architecture alteration in the hindlimb-unloaded rat model of bone loss: Sex differences. Am J Physiol Endocrinol Metab. 2006;290(3):E440-47. [PMID: 16467486]

117. Zhang Y, Ji SR, Wu CY, Fan XH, Zhou HJ, Liu GL. Observation of locomotor functional recovery in adult complete spinal rats with BWSTT using semiquantitative and qualitative methods. Spinal Cord. 2007;45(7):496-501. [PMID: 17211462]

118. Muir GD. Locomotor plasticity after spinal injury in the chick. J Neurotrauma. 1999;16(8):705-11.

[PMID: 10511243] 
119. De Leon RD, Hodgson JA, Roy RR, Edgerton VR. Locomotor capacity attributable to step training versus spontaneous recovery after spinalization in adult cats. J Neurophysiol. 1998;79(3):1329-40. [PMID: 9497414]

120. Saunders NR, Kitchener P, Knott GW, Nicholls JG, Potter A, Smith TJ. Development of walking, swimming and neuronal connections after complete spinal cord transection in the neonatal opossum, Monodelphis domestica. J Neurosci. 1998;18(1):339-55. [PMID: 9412512]

121. Fluckey JD, Dupont-Versteegden EE, Montague DC, Knox M, Tesch P, Peterson CA, Gaddy-Kurten D. A rat resistance exercise regimen attenuates losses of musculoskeletal mass during hindlimb suspension. Acta Physiol Scand. 2002;176(4):293-300. [PMID: 12444935]

122. Kunkel CF, Scremin AM, Eisenberg B, Garcia JF, Roberts S, Martinez S. Effect of "standing” on spasticity, contracture, and osteoporosis in paralyzed males. Arch Phys Med Rehabil. 1993;74(1):73-78. [PMID: 8420525]

123. Needham-Shropshire BM, Broton JG, Klose KJ, Lebwohl N, Guest RS, Jacobs PL. Evaluation of a training program for persons with SCI paraplegia using the Parastep 1 ambulation system: Part 3. Lack of effect on bone mineral density. Arch Phys Med Rehabil. 1997;78(8):799-803. [PMID: 9344296]

124. Thoumie P, Le Claire G, Beillot J, Dassonville J, Chevalier T, Perrouin-Verbe B, Bedoiseau M, Busnel M, Cormerais A, Courtillon A. Restoration of functional gait in paraplegic patients with the RGO-II hybrid orthosis. A multicenter controlled study. II: Physiological evaluation. Paraplegia. 1995;33(11):654-59. [PMID: 8584300]

125. Leeds EM, Klose KJ, Ganz W, Serafini A, Green BA. Bone mineral density after bicycle ergometry training. Arch Phys Med Rehabil. 1990;71(3):207-9. [PMID: 2317139]

126. BeDell KK, Scremin AM, Perell KL, Kunkel CF. Effects of functional electrical stimulation-induced lower extremity cycling on bone density of spinal cord-injured patients. Am J Phys Med Rehabil. 1996;75(1):29-34. [PMID: 8645435]

127. Snyder WS. Report of the task group on reference man. Oxford (England): Pergamon; 1975.

128. Bloomfield SA, Mysiw WJ, Jackson RD. Bone mass and endocrine adaptations to training in spinal cord injured individuals. Bone. 1996;19(1):61-68. [PMID: 8830990]

129. Mohr T, Podenphant J, Biering-Sorensen F, Galbo H, Thamsborg G, Kjaer M. Increased bone mineral density after prolonged electrically induced cycle training of paralyzed limbs in spinal cord injured man. Calcif Tissue Int. 1997;61(1):22-25. [PMID: 9192506]

130. Shields RK, Dudley-Javoroski S, Law LA. Electrically induced muscle contractions influence bone density decline after spinal cord injury. Spine. 2006;31(5):548-53. [PMID: 16508550]

131. Granhed H, Jonson R, Hansson T. The loads on the lumbar spine during extreme weight lifting. Spine. 1987;12(2): 146-49. [PMID: 3589805]

132. Fritton SP, McLeod KJ, Rubin CT. Quantifying the strain history of bone: Spatial uniformity and self-similarity of low-magnitude strains. J Biomech. 2000;33(3):317-25. [PMID: 10673115]

133. Serre CM, Farlay D, Delmas PD, Chenu C. Evidence for a dense and intimate innervation of the bone tissue, including glutamate-containing fibers. Bone. 1999;25(6):623-29. [PMID: 10593406]

134. Ivanusic JJ, Mahns DA, Sahai V, Rowe MJ. Absence of large-diameter sensory fibres in a nerve to the cat humerus. J Anat. 2006;208(2):251-55. [PMID: 16441569]

135. Konttinen Y, Imai S, Suda A. Neuropeptides and the puzzle of bone remodeling. State of the art. Acta Orthop Scand. 1996;67(6):632-39. [PMID: 9065083]

136. Bjurholm A, Kreicbergs A, Brodin E, Schultzberg M. Substance P- and CGRP-immunoreactive nerves in bone. Peptides. 1988;9(1):165-71. [PMID: 2452430]

137. Garcia-Castellano JM, Diaz-Herrera P, Morcuende JA. Is bone a target-tissue for the nervous system? New advances on the understanding of their interactions. Iowa Orthop J. 2000;20:49-58. [PMID: 10934625]

138. Chantraine A, van Ouwenaller C, Hachen HJ, Schinas P. Intra-medullary pressure and intra-osseous phlebography in paraplegia. Paraplegia. 1979;17(4):391-99. [PMID: 534112]

139. Chantraine A. Actual concept of osteoporosis in paraplegia. Paraplegia. 1978;16(1):51-58. [PMID: 733286]

140. Dupont-Versteegden EE, Houle JD, Dennis RA, Zhang J, Knox M, Wagoner G, Peterson CA. Exercise-induced gene expression in soleus muscle is dependent on time after spinal cord injury in rats. Muscle Nerve. 2004; 29(1):73-81. [PMID: 14694501]

141. Henderson CE, Phillips HS, Polluck RA, Davies AM, Lemeulle C, Armanini M, Simmons L, Moffet B, Vandlen RA, Simpson LC. GDNF: A potent survival factor for motoneurons present in peripheral nerve and muscle. Science. 1994;266(5187):1062-64. [PMID: 7973664$]$ Erratum in: Science. 1995;267(5199):777.

142. Snider WD, Lichtman JW. Are neurotrophins synaptotrophins? Mol Cell Neurosci. 1996;7(6):433-42. [PMID: 8875427]

143. DiStefano PS, Friedman B, Radziejewski C, Alexander C, Boland P, Schick CM, Lindsay RM, Wiegand SJ. The neurotrophins BDNF, NT-3, and NGF display distinct patterns of retrograde axonal transport in peripheral and central neurons. Neuron. 1992;8(5):983-93. [PMID: 1375039] 
144. Koliatsos VE, Clatterbuck RE, Winslow JW, Cayouette $\mathrm{MH}$, Price DL. Evidence that brain-derived neurotrophic factor is a trophic factor for motor neurons in vivo. Neuron. 1993;10(3):359-67. [PMID: 8080464

145. Gomez-Pinilla F, Ying Z, Opazo P, Roy RR, Edgerton VR. Differential regulation by exercise of BDNF and NT-3 in rat spinal cord and skeletal muscle. Eur J Neurosci. 2001; 13(6):1078-84. [PMID: 11285004]

146. Aagaard P, Simonsen EB, Andersen JL, Magnusson P, Dyhre-Poulsen P. Neural adaptation to resistance training: Changes in evoked V-wave and H-reflex responses. J Appl Physiol. 2002;92(6):2309-18. [PMID: 12015341]

147. Sale DG, MacDougall JD, Upton AR, McComas AJ. Effect of strength training upon motoneuron excitability in man. Med Sci Sports Exerc. 1983;15(1):57-62. [PMID: 6843320]

148. Skinner RD, Houle JD, Reese NB, Berry CL, Garcia-Rill E. Effects of exercise and fetal spinal cord implants on the H-reflex in chronically spinalized adult rats. Brain Res. 1996;729(1):127-31. [PMID: 8874885]

149. Trimble MH, Du P, Brunt D, Thompson FJ. Modulation of triceps surae H-reflexes as a function of the reflex activation history during standing and stepping. Brain Res. 2000;858(2):274-83. [PMID: 10708678]

Submitted for publication February 9, 2007. Accepted in revised form August 15, 2007. 